\title{
Crop-Livestock Farming Systems Varying with Different Altitudes in Southern Ethiopia
}

\author{
Nina Österle ${ }^{1}$, Ayana Angassa ${ }^{2^{*}}$, Assefa Tadesse $^{2}$, Abule Ebro $^{3}$, Joachim Sauerborn ${ }^{1}$ \\ and Anna C. Treydte ${ }^{1}$
}
${ }^{1}$ Agroecology in the Tropics and Subtropics, University of Hohenheim, Garbenstr. 13, 70599 Stuttgart, Germany
${ }^{2}$ School of Animal and Range Sciences, Hawassa University, Post Box No: 05, Ethiopia
${ }^{3}$ Adami Tulu Agricultural Research Centre, Ziway, Post Box No: 35, Ethiopia

\begin{tabular}{|c|c|}
\hline Abstract & Article Information \\
\hline \multirow{10}{*}{$\begin{array}{l}\text { In Sub-Saharan Africa, rangeland is increasingly converted to cropland, creating } \\
\text { diverse crop-livestock practices in different environments. As these practices } \\
\text { lead to highly adapted livestock production systems using resources that vary } \\
\text { locally and seasonally, not much is known about their similarities and } \\
\text { differences. We assessed different crop-livestock systems through } 60 \text { semi- } \\
\text { structured interviews in lowlands ( }<1700 \text { m.a.s.I), mid-altitude ranges ( } 2000 \\
\text { masl), and highlands ( }>2400 \text { m.a.s.l) around the Rift Valley, Ethiopia. Average } \\
\text { livestock numbers per household were higher in lowlands (43) and highlands } \\
\text { (18), where access to communal grazing lands was possible. Cattle dominated } \\
\text { at all sites, draught oxen numbers increased with available cropping land per } \\
\text { household. All sites used crop residues as supplemental feed. Dung was used } \\
\text { as manure in most households, as fuel is used only in higher regions. Our study } \\
\text { showed that crop-livestock practices and livestock numbers can be explained by } \\
\text { altitude but also by the availability of private and communally used land. Further } \\
\text { practices should include growing fodder legumes, crop rotations, and } \\
\text { intercropping, which might support a reduced-tillage system and reduce } \\
\text { numbers of environmentally costly draught oxen. }\end{array}$} & $\begin{array}{ll}\text { Received } & : 11-11-2012 \\
\text { Revised } & : 29-12-2012 \\
\text { Accepted } & : 29-12-2012\end{array}$ \\
\hline & Keywords: \\
\hline & Cattle \\
\hline & Dung \\
\hline & Manure \\
\hline & Seasonal Feed Shortage \\
\hline & Supplemental Feed \\
\hline & ${ }^{\star}$ Corresponding Author: \\
\hline & Ayana Angassa \\
\hline & \\
\hline
\end{tabular}

\section{INTRODUCTION}

In Sub-Saharan Africa, land is increasingly being converted to cropland, competing with the area available for livestock farming (Körber et al., 2009). About $75 \%$ of Sub-Saharan highlands are located in Ethiopia and Kenya, and characterized by bimodal rainfall, have a high productive potential supporting high human population and livestock density (Otte and Chilonda, 2002). The largest livestock population of entire Africa is located in Ethiopia (Gebremedhin et al., 2004; Gryseels and Anderson, 1983). The high variation in elevations have affected vegetation and natural constraints locally, and the availability of feeding resources such as pastures, crop residues, and concentrates have led to diverse livestock systems in Ethiopia (Seré et al., 1995). There are no studies on how strongly these croplivestock farming systems in Ethiopia differ, yet, while research on livestock practices has mainly addressed rangelands in Borana, Southern Ethiopia (Alemayehu, 1998; Angassa and Oba, 2010 ), and the mid-Rift valley (Mohammed and Bekele, 2010; Sisay and Baars, 2002).

This study aimed at displaying the differences in crop production and livestock keeping practices that occur among regions varying in elevation, agro-ecological circumstances and cultural affiliation in southern Ethiopia. We assessed livestock species and numbers, quantified input (pasture feed, crop residues, concentrates, cut-and- 
Nina Österle et al.,

carry techniques) and output (dung use as manure, fuel) of the different crop-livestock systems, compared among the regions.

\section{Land Property and Use}

In Ethiopia, semi-arid zones, with low annual average rains of 500 to $750 \mathrm{~mm}$, are best suited for rangeland grazing but also mixed small holder crop-livestock systems prevail, in which open grassland and crop residues are used for feeding livestock (Otte and Chilonda, 2002). Due to higher and more reliable rains, highland zones are better suited for cropping (Otte and Chilonda, 2002). The dominance of particular plant types, including crop types, is highly dependent on elevation, average rainfall and temperature, and the length of the growing period (Pearson, 1992). Cropping in lower regions below 1700 masl is usually based on either maize (Zea Mays) or sorghum (Sorghum spp). At mid altitudes, between 1700 and 2400 masl, teff (Eragrostis abyssinica), a unique agricultural feature of Ethiopia, is of increasing importance. Pearson (1992) recorded, that the proportion of wheat (Triticum spp.), barley (Hordeum vulgare) and oat (Avena spp.) increases with higher altitude, becoming major crops in areas above 2400 masl (Pearson, 1992). Further, cropping systems are divided into cereal-based and enset-based ones (Pearson, 1992), enset (Ensete ventricosum) being a root crop of high nutrient requirements, which is characteristic for southern Ethiopia (Funte et al., 2010). Therefore, its abundance is related to arable land of rather high soil nutrient quality, and depends on livestock, which provides sufficient manure for enset. On the other hand, residues of enset leaves are favorable animal feed, so both enset and livestock support each other (Funte et al., 2010). Hence, we hypothesized:

a. The grassland proportion in farmlands is higher in the low and therefore drier regions, while in highlands the proportion of cropping area is higher.

b. Major crops in the lowlands (<1700 masl) are maize and/or sorghum, in the mid-altitude sites (1700 to 2400 masl) teff, and in highland regions (>2400 masl) wheat, barley and oat. Enset will occur across all elevations.

\section{Livestock}

The main feed resources in the Mid Rift Valley of Ethiopia are natural pastures (Sisay, 2000) but mixed crop-livestock systems prevail. The number of animals owned by a farmer is limited by the number of animals that can be fed during the dry season, when livestock feed is in short supply. The availability of crop residue plays a
Sci. Technol. Arts Res. J., Oct-Dec 2012, 1(4):01-13

key-role in animal feeding during times of feed scarcity (Funte, 2006). One constraint in livestock production in Ethiopia is inadequate feed supply both in terms of quality and quantity (Beyene, 2009). Independently of the animals' condition, farmers are aiming to keep as many animals as possible, as stock size represents a farmer's social position (Sisay, 2000).

Several factors account for the livestock species owned by a household in a specific region. Cattle, sheep and goats are kept in all traditional farming systems in Sub-Saharan Africa, in varying proportion, according to the species comparative advantages and stocking capacity in each agro-ecological zone (Otte and Chilonda, 2002). These advantages consist of the species ability to adapt to the specific environmental and institutional conditions on the one hand, and to fit to local conditional requirements of the farmers on the other (Seré et al., 1995). Requirements of farmers are milk and meat as food resource, oxen for draught power and equines for transport. As the main source of traction in Ethiopia is oxen, regions with higher proportion of cropping area have a proportionally higher need for oxen (Otte and Chilonda, 2002). Livestock in general serves as a source of income and as an asset (Funte, 2006). Environmental factors, such as low rainfall, influence on the one hand the animals' physiological suitability, but also the farmers' behavior for risk aversion. In regions with erratic rainfall and periodic droughts, small ruminants with low feed requirements and a high reproduction rate are well adapted to seasonal feed shortage and play an important role (Seré et al., 1995).

Due to their favorable conditions, the highlands have the highest density of both, people and livestock (Otte and Chilonda, 2002). Institutional conditions, such as restrictions on land use and the availability of communal grazing lands, influence livestock keeping capacities of individual households, independently of their own land. In Ethiopia in general, cattle are the most important and most frequent livestock species, followed by sheep and goats, counted in heads (Otte and Chilonda, 2002). Thus, we stated the following hypotheses:

a. The proportion of small ruminants is higher in lower regions with lower and erratic rainfall.

b. The number of trek oxen rises proportionally to the size of the crop area.

c. Overall livestock numbers per farmer are higher in highlands.

d. Farmers with access to communal land own more livestock. 


\section{Animal Feed}

The main feed resource for livestock in the Mid Rift Valley has been the herbaceous layer of rangelands (Sisay, 2000). However, during the dry period, crop residues and straw from cereal legumes become highly relevant as supplemental feed sources (Sisay, 2000; Suttie, 2000). According to Pearson (1992) no fodder legumes were grown in the Ethiopian highlands at the time of his research. Since then, improved fodder technologies and forage seeds have been invented and applied in certain areas of Ethiopia (Muzein, 2010). We therefore expected:

a. Livestock mainly feed on natural pasture and crop residues, with a higher proportion of crop residues being the feed source during the dry season. Feed supply is dependent on the size of land property, which determines livestock keeping capacity.

b. Feed shortage occurs towards the end of the dry season when crop residues are used up and are getting scarce.

c. Due to land shortage, farmers usually do not grow any fodder plants in addition to their own food production crops.

\section{Dung Use}

An important factor that integrates livestock into crop farming systems is their effect on soils (Pearson, 1992). Livestock convert vegetative plant material and residues to dung, as manure a valuable resource to maintain fertility of pasture and especially of cropland (Harris, 2002). However, the use as fertilizer often competes with the use of dung as fuel for fire as the availability of firewood is often limited (Lupwayi et al., 2000). In Sub-Saharan Africa, artificial fertilizer is not affordable for most small-scale farmers and manure is a key resource for maintaining nutrient balances in the soil of cropping areas (Lupwayi et al., 2000). In some cases, pastoralists collaborate with crop farmers in Sub-Saharan Africa such that animals can feed on the crop residues while crop farmers benefit from the recycled nutrients given back to the soil via animal manure (Seré et al., 1995). In the Ethiopian highlands, people use some manure as fertilizer, but the average household uses about $2000 \mathrm{~kg}$ of dry matter manure per year as a fuel for burning (Otte and Chilonda, 2002), which is because of higher opportunity costs for alternative fuels in the highlands (Shiferaw and Holden, 1999). Hence, we hypothesized:

a. In the highlands, the proportion of dung used for burning is higher than that used as manure. b. Dung as manure is more frequently used than artificial fertilizer.

c. In areas with high proportion of cropping areas, herders might have agreements with crop farmers for herding their animals on crop residues.

\section{MATERIAL AND METHODS}

\section{Study Area}

The study was conducted in southern Ethiopia in two zones of the Southern Nations, Nationalities and Peoples Regional State (SNNPRS) and of Oromia region, respectively. Study sites were chosen according to their environmental conditions, focusing on elevation and climatic characteristics, but also considering infrastructure and accessibility. Of the SNNPRS region, the Guarage and the Sidama zones were selected, in Oromia region the east Shewa and western Arsi zones were selected. Hence, our selection covered the lowland and the lakes of the Mid Rift Valley and the adjacent mountains, mid-altitude lands and highlands. Along the Mid Rift Valley, elevation stretches from 1500 masl to 2500 masl, and yearly rainfall increases with elevation from $600 \mathrm{~mm}$ to $1500 \mathrm{~mm}$. The mean temperature is highest in the lowest regions with up to $26^{\circ} \mathrm{C}$ and lowest in the highest regions with $11^{\circ} \mathrm{C}$ (Sisay, 2000). The study sites can be categorized into low, mid, and high altitudes, into different rainfall intensities (duration and location of rainy season) and different average temperatures. The east Shewa zone of Oromia region and the Sidama zone in SNNPRS represent the lowlands, the mid-altitudes are covered by the Guarage zone, and the west Arsi zone in Oromia region is representative for the highlands. The characteristics of each study district are described below:

Adami Tulu Jido Kombolcha District (AT): In the east Shewa zone of Oromia region, the Adami Tulu Jido Kombolcha district, inhabiting Oromo people, was chosen to conduct the interviews. Ziway town $\left(07^{\circ} 55^{\prime} \mathrm{N}, 38^{\circ} 42^{\prime} \mathrm{E}\right)$ is the administrative centre of the district, part of the Mid Rift Valley. Three peasant associations named Aneno Shisho, Desta Abijeta and Edo Gojola were selected, based on the recommendation of the Adami Tulu Research Centre staff, to cover all main characteristics of the district. Five households were interviewed in each peasant association. The average altitude of the sites visited in AT was about 1600 masl. The area consists of $99 \%$ flatland (Sisay, 2000), average temperature is $21^{\circ} \mathrm{C}$, mean annual rainfall $750 \mathrm{~mm}$ (Adami Tulu Research Centre, 2010), with high inter-annual variation over the 
Nina Österle et al.,

last decades between $>1000 \mathrm{~mm}$ and $550 \mathrm{~mm}$ (Sisay, 2000). The small rainy season starts in February, lasting to June and the main rainy season starts in July, lasting up to September/October (Adami Tulu Research Centre, 2010).

Umbullo Wacho watershed (UW): In the Sidama zone in SNNPRS, the Umbullo Wacho Watershed was chosen as research site. UW is part of the the Hawassa Zuria district, bordering the western shore of Lake Hawassa $\left(7^{\circ} 3^{\prime} \mathrm{N}\right.$ and $38^{\circ} 28^{\prime} \mathrm{E}$; Costa Perez et al., 2003) and hosting Sidama people. The watershed consists of the three peasant associations Umbullo Wacho, Tenkaka Umbullo and Kejima Umbullo. Five households were interviewed in each of the peasant associations. UW is about 1800 masl high and characterized by two flat areas where the main farming activities take place, intersected by one steep area (Costa Perez et al., 2003). Average temperature is $24^{\circ} \mathrm{C}$ (Funte, 2006), mean annual rainfall is $1067 \mathrm{~mm}$ (Funte et al., 2010). The first and short rainy season usually takes place between March and May, the second and longer rainy season starts in June, lasting up to October (Funte et al., 2010).

Beresa watershed (BW): In the Guarage zone in SNNPRS, the research was undertaken in the Mesqan district, with Butajira $\left(8^{\circ} 7^{\prime} \mathrm{N}\right.$ and $38^{\circ} 22^{\prime} \mathrm{E}$ ) as administrative centre for the residing Guarage people. Interviews in BW were conducted in two peasant associations, Dobo Tuto and Beresa, for seven and eight households, respectively. Average altitude of the visited sites was about 2000 masl, comprising flat and hilly areas. Some steep, hilly sides are protected from human and livestock use for their regeneration and rehabilitation (pers. obs.). The annual average temperature is $19^{\circ} \mathrm{C}$, mean average rainfall about $1225 \mathrm{~mm}$ (Agricultural Office, 2010). Rainfall is bimodal with the first rainy season occurring in March and April and the second and longer rainy season occurring from June to October (Beyene, 2009).

Dodola district (DD): In the Bale zone in Oromia region, study sites were located in Dodola district, the administrative centre being Dodola (DD; $6^{\circ} 58^{\prime} \mathrm{N}$ and $39^{\circ} 11^{\prime} \mathrm{E}$ ). Interviews were conducted in four different peasant associations, five of them in Barrisa, four in Deneba and Dobo Tutu, respectively, and two in Leensho. The peasant associations, home for Oromo people, were located at about 2500 masl, the highest elevation of all sites visited. The area is plain and suitable for natural grazing and agricultural mechanization. The annual average
Sci. Technol. Arts Res. J., Oct-Dec 2012, 1(4):01-13

temperature is $17^{\circ} \mathrm{C}$, mean annual rainfall 855 $\mathrm{mm}$, with bimodal distribution. The short rainy season starts in February and goes until April; the second and longer rainy season starts in June, lasting until August (Agricultural Office, 2010).

\section{Data Collection}

A survey of 60 households was conducted in April and May 2010. Survey populations were selected within the investigation areas from at least two different peasant associations per area. These were chosen for several criteria, according to information provided from the Hawassa University and the Adami Tulu Research Centre and based on a geographical map of the area. Peasant associations were selected such that differences in elevation within one study area were minimized, and to cover a wide range of the district and appropriate accessibility for interviewers within the given time frame and means. In peasant associations, 15 sample units were selected through random walks in each area, summing up to a total of 60 interviewed households.

A structured, partly standardized questionnaire with open and closed questions was used for oral interviews according to Kromka (2009). The questionnaire was subdivided into three parts. The first part covered general data such as the size and use of the farmer's land, the livestock species constellation, number of livestock and their main purpose. The second part encompassed questions on species composition of pasture and crops, use of supplemental feed and seasonal specification in feeding while the third part contained questions on dung use. The interview questions of the questionnaire document were pre-tested and adapted based on results from the UW study sites. With the help of the pre-test and local experts the occurring local conditions, difficulties and constraints were assessed and the interview methodology adjusted accordingly.

The interviews were conducted together with the help of local experts, such as "developmental agents", i.e., staff of the respective Agricultural Offices supporting and administrating local farmers, staff of the Hawassa University Operational Research Team and of the Adami Tulu Research Center. There was one team of "enumerators" working in each area that was familiar to local conditions and had proficiency in English and the local languages, respectively. Interviewers were instructed theoretically and practically previous to the sampling and during sample interviews of the pre-tests. 


\section{Data Analysis}

The information derived from the interviews contained both qualitative and quantitative data. Some qualitative data were converted to categorical values using nominal scales. PASW Statistics (Version 18.0.0) was used for statistical analysis. General linear models were used for univariate analysis of variance (ANOVA) with "districts" as independent variables and all reviewed characteristics of the farming systems such as stock sizes and size of land as dependent variables. LSD Post-hoc tests were conducted for the least significant differences of group means of the districts.

\section{RESULTS}

\section{Land Property and Use}

All households interviewed were in possession of acreage (Table 1). The average size of the landholding, consisting of crop land and natural pasture, owned by one farmer was around 1 ha in the mid-altitudes and three and six times as large in the low- and highlands, respectively $(F=13.8$, $P<0.01)$. The proportion of crop land was highest in BW, the site with the lowest overall farming land, and lowest in the highlands, where overall land properties were largest $(F=3.9, \quad P<0.05)$.
Accordingly, the proportion of pasture followed the opposite trend (Table 1). Further, communal grazing lands were common in the lowlands and in the highlands, in the latter area used by almost all farmers while in the lowlands only about half the farmers accessed communal lands. Communal land in BW was grassland, but with less than $10 \%$ that of the low- and highlands on much smaller ground and for cut and carry feeding only. While in the lowlands, the communal lands were mainly grasslands, in the highlands the land that was used communally was mainly crop residue land, accessible only seasonally after harvesting times.

In the lower regions, the major crop was maize, covering $74 \%, 65 \%$, and $36 \%$ of the cropping land in AT, UW (with haricot bean in an intercropping system), BW, respectively. In contrast, at DD in the highlands, a high proportion of wheat $(46 \%)$ and barley (25\%) were cultivated. Enset was mainly grown in the mid-altitude sites in UW with $21 \%$, while teff comprised $5 \%, 36 \%$, and $13 \%$ at AT, BW and DD, respectively. Variation in cultivated crops was high, particularly amongst areas where farmland was small.

Table 1: Land property, land use and dung utilization in the study sites.

\begin{tabular}{lcccc}
\hline \multirow{2}{*}{ Study Site } & AT & UW & BW & DD \\
\cline { 2 - 5 } & Lowlands & \multicolumn{2}{c}{ Mid-altitude } & Highlands \\
\hline Average elevation (masl) & 1600 & 1800 & 2000 & 2500 \\
Average acreage/household (ha \pm SE) & $3.5 \pm 0.6^{\mathrm{b}}$ & $1.3 \pm 0.2^{\mathrm{a}}$ & $0.8 \pm 0.1^{\mathrm{a}}$ & $5.9 \pm 0.9^{\mathrm{b}}$ \\
Crop land (\%) & $86.7 \mathrm{~b}^{\mathrm{c}}$ & $82.3^{\mathrm{b}}$ & $91.7^{\mathrm{c}}$ & $80.3^{\mathrm{ab}}$ \\
Grazing land (\%) & $13.3^{\mathrm{ac}}$ & $17.7^{\mathrm{b}}$ & $8.3^{\mathrm{a}}$ & $19.7^{\mathrm{bc}}$ \\
\hline Communal land (ha) & 600 & - & 6.2 & 406 \\
$\quad$ Benefiting households (\%) & 47 & 0 & 47 & 93 \\
\hline Use of dung as & & & & \\
$\quad$ Manure (\%) & 78 & 100 & 32 & 29 \\
$\quad$ Fuel (\%) & 20 & 0 & 68 & 64 \\
Other (\%) & 2 & 0 & 0 & 7 \\
\hline$\%$ wood out of total fuel material & 90 & 100 & 74 & 60 \\
$\%$ dung out of total fuel & 10 & 0 & 26 & 40 \\
\hline A & & & & \\
\hline
\end{tabular}

AT = Adami Tulu, UW = Umbullo Wachu, BW = Beresa Watershed, DD = Dodola (see also Methods). Different letters indicate significantly different values according to LSD post-hoc tests $(P<0.01)$.

\section{Livestock}

Livestock species composition consisted of cattle, goats, sheep, equines and poultry in all reviewed zones (Figure 1). The average cattle stock size was smallest in the mid-altitude sites (BW and UW), about twice as large in the highlands, and four times as large in the lowland study site (Figure 1). The same trend was true for goats and equines, whereas the number of sheep was highest at DD, in the highland site, and half that in the lowland site (AT). However, the proportion of small ruminants among the different altitudes was not significantly different. In the lowlands, stock sizes were particularly high in the peasant association Desta Abijeta, where most people had access to large communal grazing 


\section{Nina Österle et al.,}

areas. Hence, the number of livestock herds did not follow the altitude gradient in our study. According to the average number owned by a household, cattle were the most important species over all elevations. Noticeable was the
Sci. Technol. Arts Res. J., Oct-Dec 2012, 1(4):01-13

number of goats in AT, which was more than five times as high as the number of sheep. In UW and BW, numbers of goats and sheep were on a comparable level.

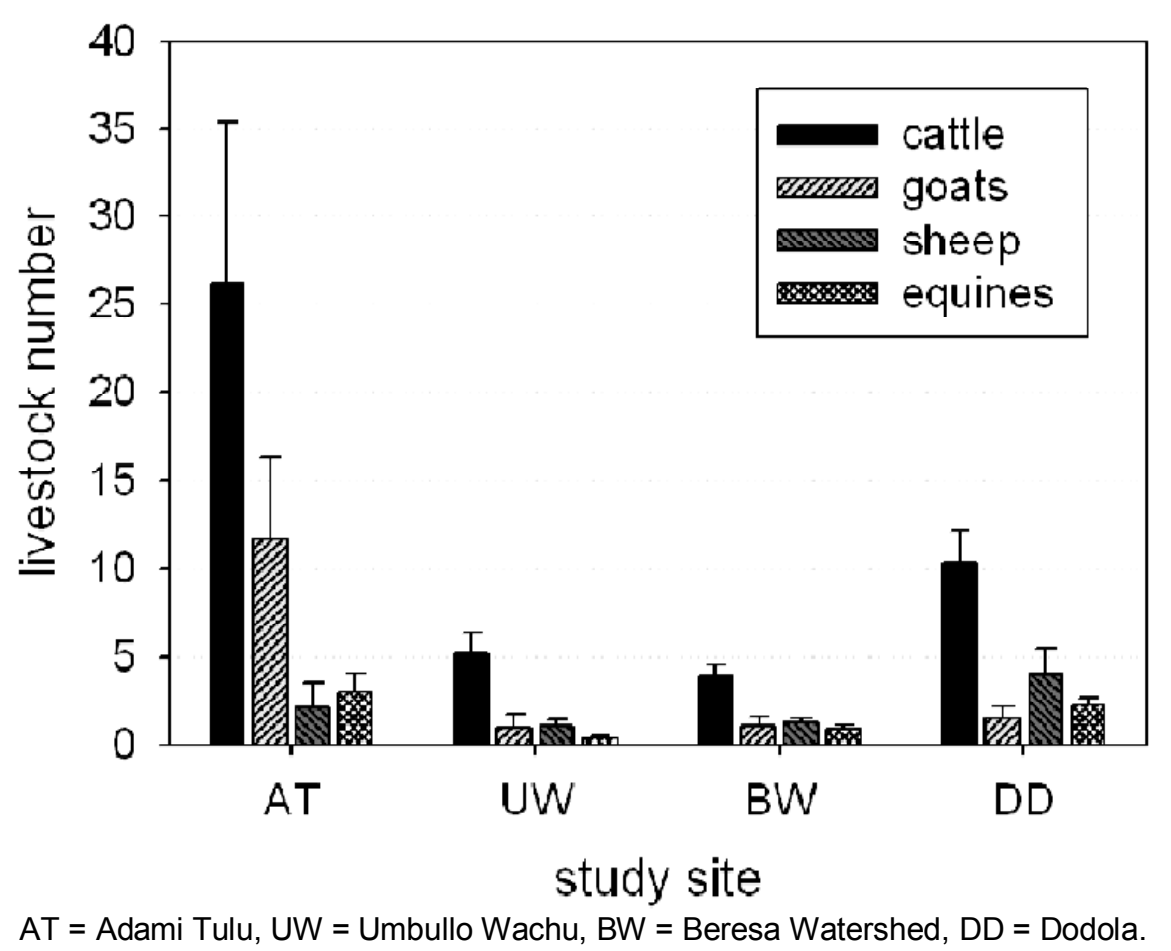

Figure 1: Livestock numbers (mean $\pm S E$ ) and species compositions for the different study sites. Study sites are listed on the $x$-axis from left to right with increasing elevation.
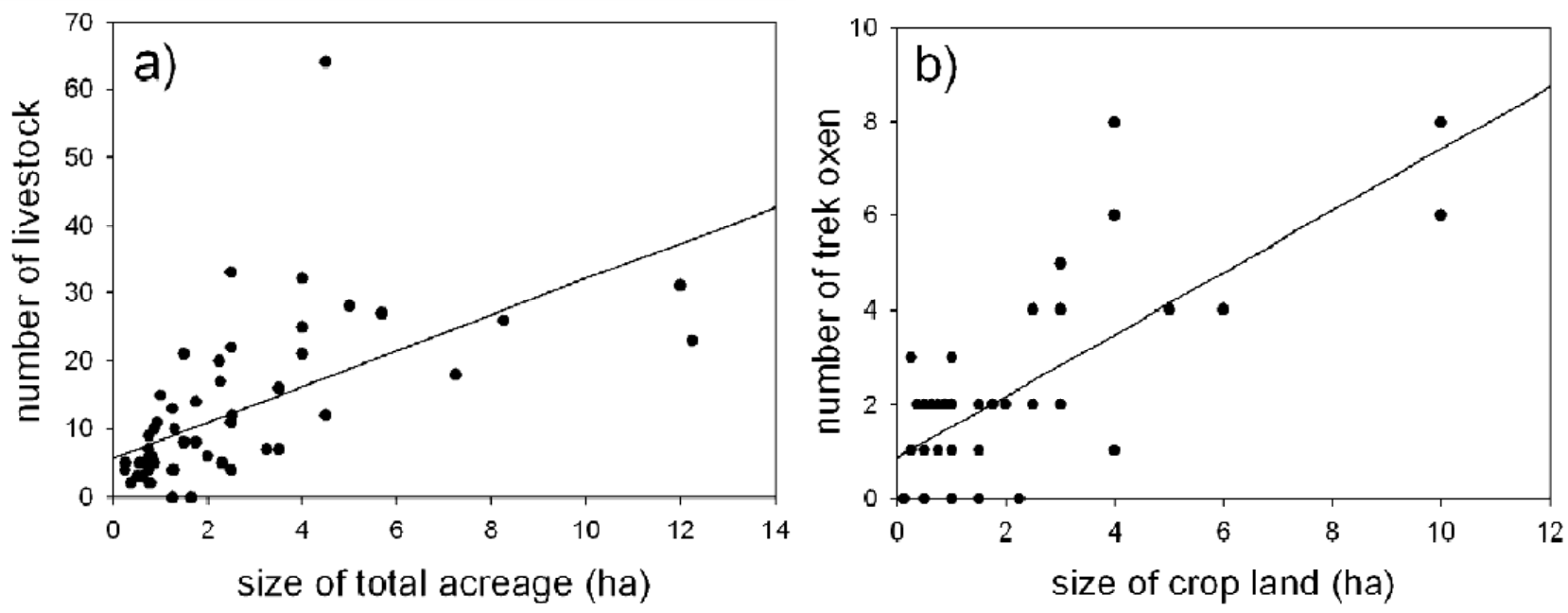

Figure 2: a) Livestock numbers versus the size of total land property owned by the respective household. Filled circles represent numbers of cattle, sheep, goats, and equines. Data from the peasant association Desta Abijeta were removed, where livestock numbers were highly influenced by communal grazing land (see also Results section).

b) Number of trek oxen versus the size of crop land per respective household. Data from the peasant association Desta Abijeta were removed, where livestock numbers are highly influenced by communal grazing land (see also Results section). 
Nina Österle et al.,

The total stock sizes in heads increased with an increasing total land property owned by the same household $\left(R^{2}=0.45, P<0.001\right)$, excluding the households of Desta Abijeta as their numbers seemed to be strongly influenced by the availability of communal grazing lands (Figure $2 a)$. The proportion of oxen displayed against the size of the cropping area (Figure. 2b) also showed a positive but weak correlation $\left(R^{2}=0.56\right.$, $P<0.001)$; here, also the households from Desta Abijeta were excluded.

In both the lowlands and highlands but not in the mid-altitude sites, $73 \%$ of the farmers split up the herd during daytime, i.e., juvenile animals stayed at the homestead while their mothers were grazing on the field. As farmers stated during the interview, this was mainly done to prevent them from suckling so that more milk remains for consumption for the household members. At night, $93 \%$ of the households in the mid-altitude sites kept the animals in the house together with the household members. In the lowlands, $73 \%$ of the households had a fenced area outside the house for the animals to stay at night, while in the highlands, $87 \%$ of the households kept their animals in separate building at night.

\section{Animal Feed}

Grazing on crop residues commenced after the harvest and, therefore, at slightly different times in each region. It started in August in the lowlands, in September in the highlands and UW and not before October in BW. In UW it lasted until December, until March in DD, until May in AT and until June in BW (Figure 3a). Most households stated that the beginning of animal feed shortage (Figure $3 b$ ) occurred at the end of the dry season. Feed shortages occurred in all zones, starting in February, except for the highlands, where feed did not become scarce before May. With up to $100 \%$ of the households, the highest proportion of households was affected by feed shortage in UW. The shortest time of feed shortage, ending in June, affected up to $80 \%$ of the farmers in the lowlands. The lowest proportion of farmers was affected in BW, the mid-altitude site, but therefore over a longer period of time, up to September. In the highlands, feed shortage commenced late in the year, getting severe in June, affecting up to $80 \%$ of the farmers and lasting until November (Figure 3b).

During the dry season, crop residues seemed to be the main feed resource, as no or few additional concentrates were given in the lowlands and mid-altitude sites (Figure 3c). Dodola, the highland site, was the only site where all households stated that they buy concentrates
Sci. Technol. Arts Res. J., Oct-Dec 2012, 1(4):01-13

in shops while only $7 \%$ of the households fed animals with additional concentrates at the lowland site and $47 \%$ and $67 \%$ did so at BW and UW, respectively. Concentrates were used to balance deficits in feed supply from natural sources, as they were mainly fed at the time when shortage of feed was also occurring; most farmers fed concentrates from February to March.

Cut and carry feeding (Figure 3d) was practiced at all watersheds, in UW and DD partly overlapping with time of the feed shortage. In UW, farmers started with cut and carry feeding in January, reaching a peak of $87 \%$ of participation in March, which contrasted the times of cut and carry practices at the remaining study sites. In the latter, most farmers practiced cut and carry between July and October (Figure 3d). With 33\%, DD had the highest rate of households growing special fodder plants, $20 \%$ of the households were doing so in AT and UW and $7 \%$ in BW. Popular fodder plants were fodder grasses like Rhodes grass (Chloris gayana) and Elephant grass (Panicum maximum), but also several kinds of legumes and oat. Farmers in BW used the communal area for cut and carry feeding. Summing up concentrate feeding, growth of fodder plants, cut and carry feeding, the main feed for the livestock consisted of crop residues and of grazing natural pasture. Remarkable was that in the lowlands, $40 \%$ of the households did not graze their animals on stubble at all (data not shown).

\section{Dung use}

All households over all watersheds used the dung of their animals, either as manure to fertilize their soils or as fuel for burning to replace scarce firewood resources (Table 1). UW was the only site at which dung was only used for manure whereas at other sites, dung was used for both fuel and manure. The higher latitudes used dung as fuel more often compared to the lowlands and the mid-altitude sites, where wood seemed to be of major importance as fuel resource (Table 1). In DD and BW, where dung was mainly used as fuel, dung was seasonally collected and "dung cakes" were manufactured, dried and stored for burning (Figs. 4a and b). Almost half of the households in the highlands burned dung all year round, but from March to September this number raises up to $87 \%$, similar to that of BW (Figure 4c). In the higher regions, it was a common practice to add the remaining ashes from the fire to their manure resources or to distribute it directly on the field. Around $40 \%$ of the households in DD stated that they used fertilizer instead of manure from their animals to maintain the soil fertility. 
a)

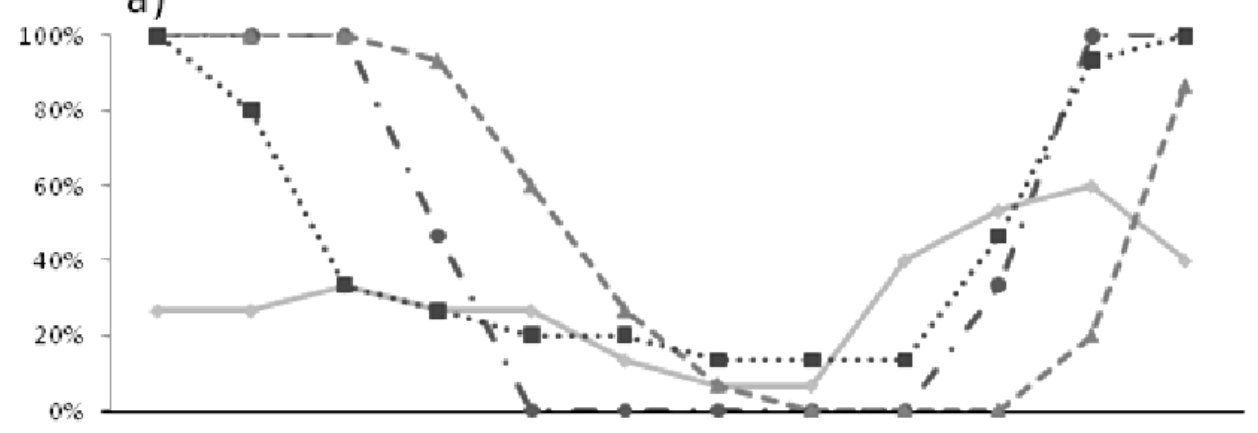

b)
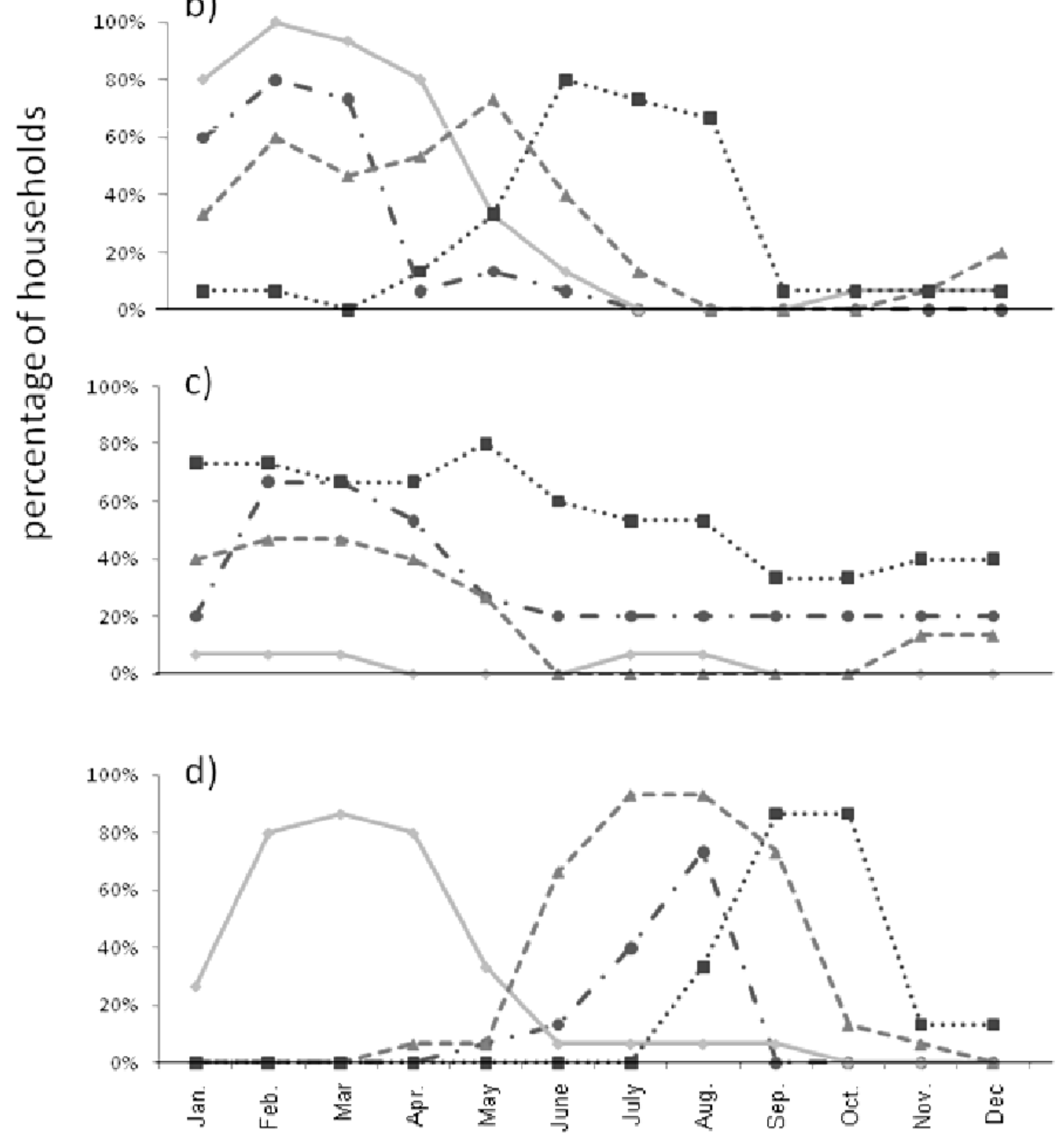

\section{months of year}

Dashed circled line $=$ Adami Tulu, Gray solid line = Umbullo Wachu, Dashed triangular line $=$ Beresa Watershed, dotted square line $=$ Dodola

Figure 3: Seasonal trends of the proportion of households interviewed feeding livestock with (a) crop residues (b) experiencing feed shortage, (c) feeding concentrates, (d) using cut and carry feed. 

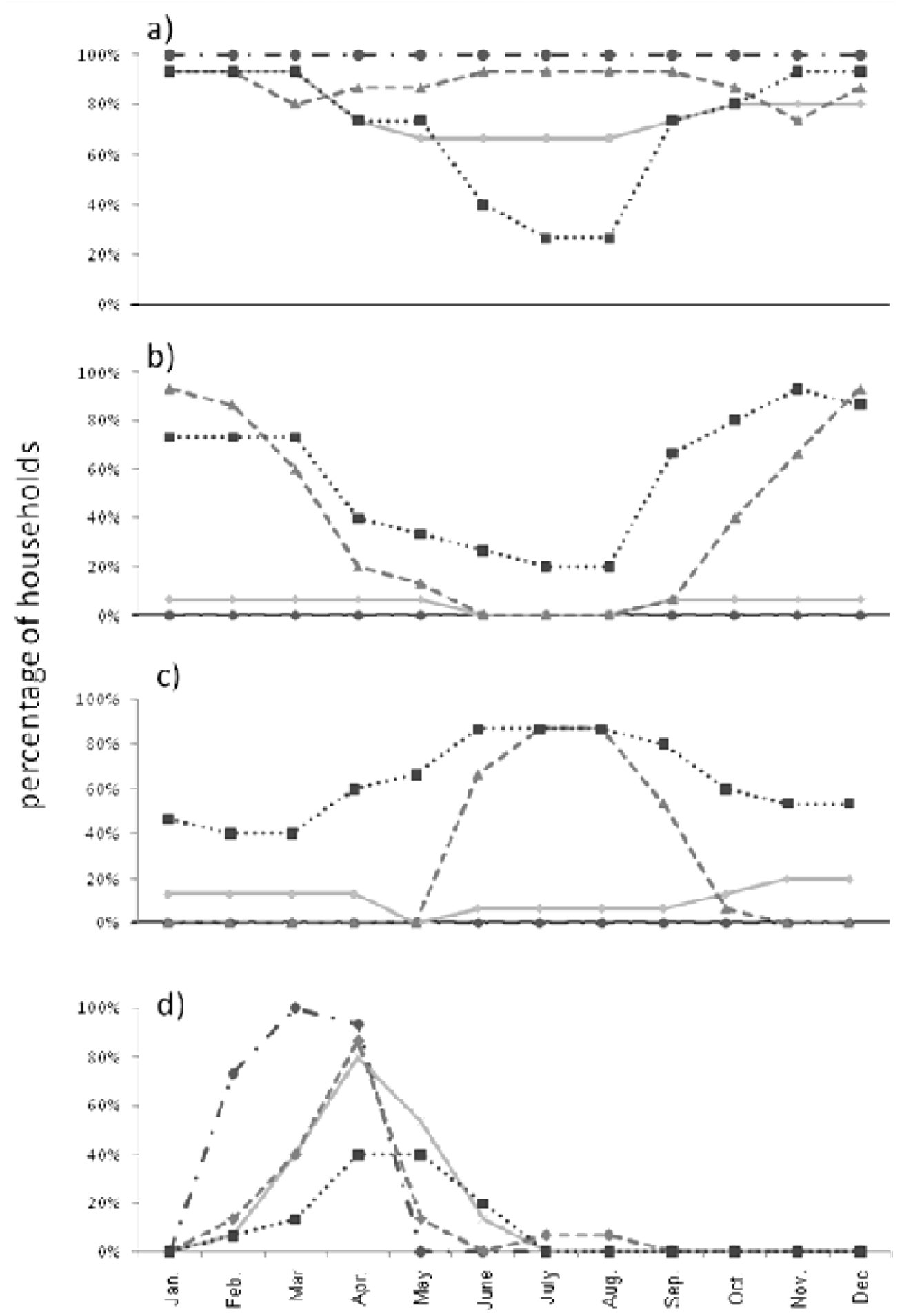

months of year

Dashed circled line $=$ Adami Tulu, gray solid line $=$ Umbullo Wachu, Dashed triangular line $=$ Beresa Watershed , dotted square line $=$ Dodola .

Figure 4: Seasonal trends of the proportion of households (a) collecting dung from their livestock, (b) producing "dung cakes" for fuel use, (c) burning dung as fuel, (d) applying dung as manure. 


\section{DISCUSSION}

This study has shown that the Adami Tulu Jido Kombolcha district (AT) in the lowlands and the Dodola district (DD) in the highlands were, despite their high difference in elevation, largely similar in several aspects: both showed quite an extensive area of land owned by a household, including both pasture and crop growing area, a high average number of livestock per household, and both practiced elaborate livestock keeping techniques (e.g. splitting herds up to be fed on different grounds depending on nutritional status). This might be explained by their good access to large communally used pasture (AT) or crop residue fields (DD). In more detail, our results show:

\section{Land Property and Use}

We found that pasture proportion was highest for the highlands, against our predictions, as we expected this high rainfall and fertile site to comprise more cropland, not relying on livestock as strongly as the lower regions. The Agricultural Office in Dodola District (2010) provided numbers of $67 \%$ and $33 \%$ of crop and grazing land, respectively, indicating an even higher proportion of grazing land than found in our study for DD. The high emphasis on grazing livestock might be explained by the large areas of cropping fields, which are available for livestock grazing after harvest, and were not included in our calculations. However, these crop-residues might contribute to a large extent to livestock feeding, and cause elaborate seasonal movements of livestock and their herders, resembling transhumance movements (pers. obs.), a phenomenon also highlighted, e.g., by Ladio and Lozada (2004) in Patagonia or Scoones (1995) in Zimbabwe. At the lowlands, findings by Sisay (2000) indicate that $40 \%$ of the land is attributed to grazing and $60 \%$ for cropping whereas our results show that in the lowland site AT, an even lower proportion $(13 \%)$ of each farmer's land property is attributed to grazing land. This might be caused by the communally used grazing land in AT, which was not included in the estimates for overall farming area per individual households in our study. Interviewees with access to this communal grazing land estimated its size to be around 600 ha, similar to other studies in southern Africa (Abel and Blaikie, 1989; Shackleton, 1993). According to Sisay (2000), $75 \%$ of the total grazing land in the Mid Rift Valley is communally used land. Including values of communal grazing land to our estimates of the highlands and the lowlands, our results still follow the previous pattern, when all four study sites were compared. However, there is a general tendency in Ethiopia for grazing land to be converted into cropland (Beyene, 2009). The conversion of communal grazing land in the midaltitudes UW and BW was in particular mentioned by Funte (2006) and Beyene (2009). This development obviously resulted in a decline of forage resources and intensified the need for improved fodder technologies and efficiency for an effective livestock production (Beyene, 2009).

Our expectations about the cropping system were confirmed through the results as maize was the major crop in the lower region; teff was common in the mid-altitudes and wheat and barley systems dominated in the highlands. The only study site at which farmers listed enset as one of their crops grown was UW in the midaltitude and, hence, we could not identify whether enset and cattle were positively related. Umbullo Wachu was also the only study site at which maize and haricot bean were grown in an intercropping system. Maize yield is increased when grown in an intercropping system with legumes compared to growing it solely (Yilmaz et al., 2008) as legumes such as haricot bean fix nitrogen and therefore fertilize the soil (Delwiche, 1978). This leads to the assumption that farmers in this region might apply less manure on the maize than farmers in regions with no intercropping system. Thus, more cattle manure might remain for the application on enset, which needs high soil nutrient contents to grow (Funte, 2006). In contrary to the other study sites, dung was only used for manure and does not compete with its use as a fuel in UW, which might, therefore, also facilitate the high amount of manure available for crops, e.g., enset.

\section{Livestock}

As expected, cattle, sheep, goats and equines were present at all elevations, with cattle being the most numerous species. The high stock size in the lowlands and highlands and lowest livestock numbers in the mid-altitudes might reflect the low availability of communal grazing lands for the latter sites. Funte (2006) found on average 3-4 cattle per farm in the midlands, agreeing with our results of 4-5 cattle per household (see also Fig. 1). In the highlands, the Agricultural Office of Dodola (2010) also showed similar cattle numbers 11.6 per household, compared to our study results. The low average numbers of goats, sheep and equines in the midaltitude and highland sites found in our study agree with findings by Funte (2006), Beyene (2009) and the Agricultural Office of Dodola (2010) ranging around one animal each per household. Herd size was particularly large in the lowlands (AT) compared to the other sites, where 
Nina Österle et al.,

no other literature source could be found for comparison. Here, the households with access to the large communal grazing lands were mainly those of the peasant association Desta Abijeta, which owned remarkably more livestock than those households with no access to the communal land resource, which prompted us to conduct our analyses with and without these households.

Contrary to our assumptions and to studies in the pastoral lowlands of eastern and southern Africa (Wilson, 1988), the proportion of small ruminants at lower sites in AT and UW was not statistically higher compared to the higher located BW and DD. However, a characteristic of AT was the remarkable higher proportion of goats in comparison to sheep. The importance of goats for the Mid Rift Valley besides cattle is also mentioned by Sisay (2000). Gemeda (2009) states that in times of low rainfall and, hence, inadequate feed supply goats are a thriving species due to their browsing nature. A specific characteristic of the Mid Rift Valley is the Molybdenum induced copper deficiency in plants, which also leads to copper deficiency especially in small ruminants feeding on these plants (Faye et al., 1991). Copper deficiency can cause Enzootic ataxia and leads to a soon death of the newborn and is more severe in grasses than in shrubs and woody plants (Faye et al., 1991). Hence, grazers such as sheep might be more affected by this disease than goats being browsers. Other reasons, such as cultural preferences or high market demands could also have contributed to the high number of goats in this system as was observed for systems across Africa (Wilson, 1988) and Asia (Devendra and Chantalakhana, 2002) but no further information was available.

The number of trek oxen increased with increasing crop area per household. Draught oxen for tillage have been claimed to be as important as access to land in Ethiopia and to act as the main production constraint among the poorer households (Aune et al., 2001). However, oxen are assumingly not used for plowing before reaching full body size at the age of six, serving with relatively low productivity while consuming rather high amounts of feed and requiring high additional maintenance (Aune et al., 2001). Aune et al. (2001) alternatively suggest cow traction, possibly with crossbred cows if supplementary feed can be provided or implementation of zerotillage systems, which also provide benefits in terms of soil erosion and run-off, water holding capacity and sequestering of carbon (Aune et al., 2006).
Sci. Technol. Arts Res. J., Oct-Dec 2012, 1(4):01-13

\section{Animal Feed and Dung Use}

At all study sites, farmers started feeding crop residues after the harvest and feed shortage generally occurred in the middle of the long dry season when crop residues had been exploited and rangeland conditions were poor. Despite this widely known and predictable feed shortage cycle (see, e.g., Gryseels and Anderson, 1983; Hary et al., 1996) only few farmers grew fodder plants consisting of legumes or nutritious grasses, which could have contributed highly to improving livestock feeding practices and soil conservation (Conant et al., 2001; Hess et al., 2003; Powell and Mohamed-Saleem, 1987). This phenomenon might be due to competing land use interests on rather small properties as was also recognized by Saleem (1998).

Cattle dung was used by all households as manure or as a fuel, which affects the nutrient cycling in crop-livestock systems accordingly (Harris, 2002; Lekasi et al., 2003). A higher proportion being used as fuel in the midland and highland regions BW and DD. Few households in DD stated that they did not use any manure at all as their cropping areas were located quite far away from their homesteads. Thus, they could not transport the manure over such a long distance. Some of these farmers also stated that their soil was of such high quality that there was no need to use manure. Agreements between crop farmers and herders, as found for various other systems, where livestock competes with cropping land (Seré et al., 1995), could not be confirmed in our study. Remarkable was, however, that $40 \%$ of the households in DD, i.e., the highlands, used artificial fertilizer instead of manure. Research on the use of fertilizers shows that it is influenced by numerous factors such as its profitability, the households' financial liquidity and assets, human resources and access to markets and extension services (Demeke et al., 1998). Hence, we assume that in the highlands one or several of the factors listed above might have been prevalent compared to the other study sites. Quantifying the use of manure might become important in the future as it is possibly more effective in returning soil organic carbon to the system, thereby positively influencing Csequestration potential of farming systems (Christopher and Lal, 2007).

\section{CONCLUSIONS}

While elevation and environmental conditions can explain livestock distribution and herding practices to a large extent, particularly the availability of private land and communally used pasture influenced livestock numbers 
Nina Österle et al.,

owned by individual households. Only some areas of the lowlands showed high numbers of small livestock, particularly goats, indicating that cattle as livestock is often supplemented by environmentally favoured or socio-economically preferred livestock species. Our study highlights the importance of natural input such as dung for manure compared to artificial fertilizers as this was still practiced by most households in Ethiopia. Dung burned as fuel can be seen as environmentally friendly alternative to cutting firewood in a poorly wooded habitat but might contribute to a high loss in nutrients as nutrient cycling through manure is prevented. Further studies should quantify nutrient cycling in these systems of various altitudes. Additionally, crop rotations, intercropping and legume cropping, important tools for low input farming systems, have not been practiced widely at our study sites. Exploring and extending strategies containing these points could improve productivity and maintain N-balances in soils. At our study sites, mechanization constraints were overcome by a high use of draught oxen for tillage, which have proven to be rather costly in these small-scale farming systems. Further extending and developing systems of crop rotations and intercropping and their effects on weed control and soil texture could support a reduced-tillage system, which might provide an opportunity to lower the input of the currently used draught oxen. The potential and constraints of these alternatives need to be explored further to develop sustainable coping strategies in the future.

\section{ACKNOWLEDGEMENTS}

We would like to thank Getachew Haile Beyene, Adami Tulu Research Centre, for his active support. Our gratitude also goes to Deju Wurjine, Tilahun Alemu, Yeneneh Assefa, Abiti Tadesse, Guta Ereso and Kedir Negesso for their help and tedious work in the field. Hawassa University kindly facilitated transport. We further thank all participating households for their willingness to collaborate and provide information. Parts of this study were funded by the Ministry of Science Research and the Arts of the state Baden-Württemberg, Germany.

\section{REFERENCES}

Abel, N.O.J., Blaikie, M.P. (1989). Land degradation, stocking rates and conservation policies in the communal rangelands of Botswana and Zimbabwe. Land Degradation and Development 1: 101-123

Alemayehu, M. (1998). The Borana and the 1991-92 Drought: A rangeland and livestock resource study,
Sci. Technol. Arts Res. J., Oct-Dec 2012, 1(4):01-13 Institute of Sustainable Development, Addis Ababa, pp.102

Angassa, A., Oba, G. (2010). Effects of grazing pressure, age of enclosures and seasonality on bush cover dynamics and vegetation composition in southern Ethiopia. Journal of Arid Environments 74: $111-120$

Aune, J.B., Bussa, M.T., Asfaw, F.G., Ayele, A.A. (2001). The ox ploughing system in Ethiopia: can it be sustained? Outlook in Agriculture 30: 275-280

Aune, J.B., Asrat, R., Teklehaimanot, D.A., Bune, B.T. (2006). Zero tillage or reduced tillage: the key to intensification of the crop-livestock system in Ethiopia. In: J. Pender, F. Place and S. Ehui (eds), Strategies for Sustainable Land Management in the East African Highlands, Washington DC, pp. 309.

Beyene, M.A. (2009). Feed ressource assessment in Baresa Watershed and the effect of undersowing of forage legumes in maize on dry matter yield and nutritional value of the fodder, (unpublished MSc Thesis, Hawassa University, Awassa, Ethiopia).

Conant, R.T., Paustian, K., Elliott, E.T. (2001). Grassland management and conversion to into grassland: effects on soil Carbon. Ecological Applictions 11: 343-355.

Costa Perez, M.C., Gebreye, S., Kiros, T., Muluneh, A. (2003). Participatory GIS based analysis of the main trends of land use/cover change in Umbullo Wacho Watershed, University College Cork, Cork, Ireland \& Hawassa University, Awassa, Ethiopia.

Delwiche, C.C. (1978). Legumes: past, present, and future. BioScience 28: 565-570.

Demeke, M., Kelly, V., Jayne, T.S., Said, A., Le Vallée, J.C., Chen, H. (1998). Agricultural market performance and determinants of fertilizer use in Ethiopia, Working Paper 10, Grain Market Research Project, Ministry of Economic Development and Cooperation, Addis Abeba, Ethiopia

Devendra, C., Chantalakhana, C. (2002). Animals, poor people and food insecurity: opportunities for improved livelihoods through efficient natural resource management. Outlook in Agriculture 31: 161-175.

Faye, B., Grillet, C., Tessema, A., Kamil, M. (1991). Copper deficiency in the Rift Valley of East Africa. Tropical Animal Health and Production 23:172-180.

Funte, S. (2006). Assessment of forage biomass production, available feed ressource and ressource use systems in Umbullo Wacho Watershed (unpublished MSc Thesis, Hawassa University, Awassa, Ethiopia).

Funte, S., Negesse, T., Legesse, G. (2010). Feed resources and their management systems in Ethiopian Highlands: The case of Umbullo Wacho Watershed in southern Ethiopia. Tropical and Subtropical Agroecosystems 12: 47-56. 
Nina Österle et al.,

Gebremedhin, B., Pender, J., Tesfay, G. (2004). Collective action for grazing land management in crop-livestock mixed systems in the highlands of northern Ethiopia. Agricultural Systems 82: 273290.

Gemeda, B.S. (2009). Production and Marketing systems of small ruminants in Goma district of Jimma zone, Western Ethiopia (unpublished MSc Thesis, Hawassa University, Awassa, Ethiopia).

Gryseels, G., Anderson, F.M. (1983). Research on farm and livestock productivity in the central Ethiopian highlands: Initial results, 1977-1980, International Livestock Centre for Africa (ILCA), Addis Abeba, Ethiopia

Harris, F. (2002). Management of manure in farming systems in semi-arid West Africa. Experiments in Agriculture 38: 131-148.

Hary, I, Schwartz, H.-J., Pielert, V.H.C., Mosler, C. (1996). Land degradation in African pastoral systems and the destocking controversy. Ecolocial Modelling 86: 227-233.

Hess, H.D., Monsalve, L.M., Lascano, C.E., Carulla, J.E., Diaz, T.E., Kreuzer, M. (2003). Supplementation of a tropical grass diet with forage legumes and Sapindus saponaria fruits: effects on in vitro ruminal nitrogen turnover and methanogenesis. Australian Journal of Agricultural Research 54: 703-713

Lekasi, J.K., Tanner, J.C., Kimani, S.K., Harris, P.J.C. (2003). Cattle manure quality in Maragua District, Central Kenya: effect of management practices and development of simple methods of assessment. Agriculture, Ecosystems and Environment 94: 289298.

Körber, K., Kretschmer, J., Prinz, S., Dasch, E. (2009). Globale Nahrungssicherung für eine wachsende Weltbevölkerung-Flächenbedarfund Klimarelevanz sich wandelnder Ernährungsgewohnheiten. Journal über Verbrauch von Lebensmitteln 4: 174-189 (in German).

Kromka, F. (2009). Methoden empirischer Forschung, Skriptum zur Vorlesung als Teil des Moduls Empirische Sozialforschung, 2009 (4302-210). Universität Hohenheim, Stuttgart, Germany (in German).

Ladio, A., Lozada, M. (2004). Summer cattle transhumance and wild edible plant gathering in a mapuche community of northwestern Patagonia. Human Ecology 32: 225-240.

Lupwayi, N.Z., Girma, M., Haque, I. (2000). Plant nutrient contents of cattle manures from small-scale farms and experimental stations in the Ethiopian highlands. Agriculture, Ecosystems and Environment 78: 57-63.

Mohammed, A.S., Bekele, T. (2010). Forage production and plant diversity in two managed rangelands in the Main Ethiopian Rift. African Journal of Ecology 48: 13-20.
Sci. Technol. Arts Res. J., Oct-Dec 2012, 1(4):01-13

Muzein, S.S. 2010. Food insecurity and coping strategies of farming households in Mesqan Woreda: The case of Beresa Watershed, Guraghe Zone, Southern Region (unpublished MSc Thesis, Haramaya University, Alemaya, Ethiopia).

Otte, M.J., Chilonda, P. (2002). Cattle and small ruminant production systems in sub-saharan Africa, Food and Agriculture Organization (FAO) of the United Nations, Rome.

Pearson, C.J. (1992). Cereal-based systems of the highlands of north-east Africa, in: Pearson, C.J (Ed.) Field crop ecosystems, Elsevier, Amsterdam, 277-289

Powell, J.M., Mohamed-Saleem, M.A. (1987). Nitrogen and phosphorus transfers in a crop-livestock system in West Africa. Agricultural Systems 25: 261-277.

Saleem, M.A.M. (1998). Nutrient balance patterns in African livestock systems. Agriculture, Ecosystems and Environment 71: 241-254

Scoones, I. (1995). Exploiting heterogeneity: habitat use by cattle in dryland Zimbabwe. Journal of Arid Environments 29: 221-237.

Seré, C., Steinfeld, H., Groenewold, J. (1995). World livestock production systems - Current status, issues and trends, FAO Animal Production And Health Paper, 127, Food and Agriculture Organization (FAO) of the United Nations, Rome.

Shackleton, C.M. (1993). Fuelwood harvesting and sustainable utilisation in a communal grazing land and protected area of the eastern transvaal lowveld. Biological Conservation 63: 247-254.

Shiferaw, B., Holden, S. (1999). Soil erosion and smallholders' conservation decisions in the highlands of Ethiopia. World Development 27: 739752.

Sisay, A. 2000. Herbaceous species composition, dry matter production and condition of the major grazing areas in the Mid Rift Valley of Ethiopia (unpublished MSc Thesis, Alemaya University, Alemaya, Ethiopia).

Sisay, A., Baars, R.M.T. (2002). Grass composition and rangeland condition of the major grazing areas in the mid Rift Valley, Ethiopia. African Journal of Range and Forage Science 19: 161- 166.

Suttie, J.M. (2000). Hay and straw conservation: for small-scale farming and pastoral conditions, Food and Agriculture Organization (FAO) of the United Nations, Rome.

Wilson, R.T. (1988). Small ruminant production systems in tropical Africa. Small Ruminant Research 1: 305-325.

Yilmaz, Ş., Atak, M., Erayman, M. (2008). Identification of advantages of maize-legume intercropping over solitary cropping through competition indices in the east Mediterranean region. Turkish Journal of Agricultural and Forestry 32: 111-119. 